\title{
Immunogenicity and contraceptive potential of three infertility- relevant zona pellucida 2 epitopes in the marsupial brushtail possum (Trichosurus vulpecula)
}

\author{
Janine A Duckworth, Kathryn Wilson, Xianlan Cui, Frank C Molinia and Phil E Cowan ${ }^{1}$ \\ National Research Centre for Possum Biocontrol at Landcare Research, PO Box 40, Lincoln 7640, New Zealand and \\ ${ }^{1}$ Landcare Research, Private Bag 11052, Palmerston North, New Zealand
}

Correspondence should be addressed to X Cui; Email: cuix@landcareresearch.co.nz

\begin{abstract}
In a previous study, three infertility-relevant epitopes of possum ZP2 (Pep12 (amino acids 111-125), Pep31 (amino acids 301-315), and Pep44 (amino acids 431-445)) were identified using sera from possums (Trichosurus vulpecula) immunized with recombinant possum zona pellucida 2 (ZP2) constructs, and a synthetic peptide library of possum ZP2 protein. In this study, the three peptides were conjugated to keyhole limpet hemocyanin and $300 \mu \mathrm{g}$ of each conjugated peptide were administered subcutaneously to female possums $(n=20$ per peptide) in complete Freund's adjuvant. Immunogen doses were repeated 3 and 6 weeks later using incomplete Freund's adjuvant. Control animals were immunized with either phosphate-buffered saline only $(n=10)$ or $300 \mu \mathrm{g}$ keyhole limpet hemocyanin $(n=10)$, administered with the same adjuvants. Serum antibodies from animals immunized against these three epitopes bound to the corresponding possum ZP2 peptides, recombinant possum ZP2 protein constructs, and native zona. Possum fertility was assessed following superovulation and artificial insemination. Peptides Pep12 and Pep31 had no significant effects on fertility parameters $(P>0.05)$. However, animals immunized with Pep44 had lower egg fertilization rates (immunized $19.5 \%$ versus control $60.5 \%, P<0.05$ ) and produced significantly fewer embryos than control animals (immunized 0.5 embryos versus control 2.4 embryos, $P<0.05$ ). The number of Pep44-immunized females that produced embryos was reduced by $64 \%$. Identification and characterization of possum infertility-relevant epitopes on possum ZP2 protein will assist development of safe, humane, and possum-specific immunocontraceptive vaccines for controlling the introduced possums in New Zealand.

Reproduction (2007) 133 177-186
\end{abstract}

\section{Introduction}

The mammalian zona pellucida (ZP) is an extracellular matrix that surrounds the mammalian egg. The $\mathrm{ZP}$ is composed of three glycoproteins, namely ZP1, ZP2, and ZP3 (Harris et al. 1994), and is involved in several critical stages of the fertilization process (Hoodbhoy \& Dean, 2004, Wassarman 2005). Immunization with porcine ZP (pZP) results in a reduction in fertility in a wide range of species (Gupta et al. 2004, Kirkpatrick \& Frank, 2005), including rabbits (Dietl et al. 1982, Bhatnagar et al. 1992), dogs (Mahi-Brown et al. 1985), hamsters (Hasegawa et al. 1992), bonnet monkeys (Bagavant et al. 1994), wild horses and deer (Turner et al. 1996, Kirkpatrick et al. 1997, Miller et al. 1999), possums (Duckworth et al. 1999), wallabies (Kitchener et al. 2002), and 29 captive exotic species (Frank et al. 2005). Native ZP and recombinant ZP (rZP) components have also been tested for immunocontraception in their homologous species (Gupta et al. 2004, Kirkpatrick \& Frank 2005), including rabbits (Kerr et al. 1999), brushtail possums (Duckworth et al. 1999), dogs (Srivastava et al. 2002), bonnet monkeys (Govind et al. 2002), and mice (Clydesdale et al. 2004) with some success. A recombinant myxoma virus expressing rabbit rZP2 had no effect on fertility or ovarian histology, but such virus expressing rabbit rZP3 induced infertility in $70 \%$ of rabbits at the first breeding (Mackenzie et al. 2006).

The brushtail possum (Trichosurus vulpecula) is a major pest species in New Zealand (Cowan 2000). The development of immunocontraceptive vaccines to reduce the breeding success of possums may provide an effective and humane long-term method of population control. Previous vaccine trials have shown that immunization of possums with possum rZP2 and rZP3 proteins reduced the fertility of female animals by 72-80\% (Duckworth et al. 1999). In order to develop possum-specific vaccines, three infertility-relevant 
epitopes on possum ZP2 protein have been identified using a possum ZP2 synthetic peptide library (Cui \& Duckworth 2005). The aim of this study was to assess the ability of possum ZP2 peptide epitope vaccines to elicit immune responses in female possums and to determine whether immunization against these peptides interfered with ovarian function and fertility.

\section{Materials and Methods}

\section{Immunogens}

Three infertility-relevant possum ZP2 epitopes were identified in three possum ZP2 peptides, Pep12 (amino acids 111-125, YRVNLKFLPNETTSN), Pep31 (amino acids 301-315, VAVESRNGSRLHFNK), and Pep44 (amino acids 431-445, AIYENEIHALWADLP; Cui \& Duckworth 2005). Each peptide was synthesized and conjugated in two forms by Mimotopes, Melbourne, Australia. First, peptides with an additional cysteine residue at the $\mathrm{C}$-terminus were synthesized and conjugated to keyhole limpet hemocyanin (KLH; Lee et al. 1980) and were used for immunizations. Peptide sequences were confirmed by $\mathrm{N}$-terminal sequencing using Edman degradation prior to conjugation. Secondly, biotin was attached to the $\mathrm{N}$-terminal end of each peptide by a four-glycine linker (-GGGG-; Tribbick 1993) and these peptides were used for ELISA.

\section{Animals and immunizations}

All experimental procedures were carried out with the approval of the Animal Ethics Committee of Landcare Research, Lincoln, and were performed in accordance with the 1987 Animals Protection (Codes of Ethical Conduct) Regulations of New Zealand. Eighty wild adult female $(3.4 \pm 0.1 \mathrm{~kg})$ and 40 adult male $(>2.50 \mathrm{~kg})$ brushtail possums were captured from Lewis Pass, Canterbury, New Zealand. Animals were housed indoors in individual cages for a physical and immunological acclimatization period of 6-12 weeks (Buddle et al. 1992). At least 10 days before the experimental period, female possums were transferred, in pairs matched by body weight, into outdoor pens $(4 \times 4 \mathrm{~m})$ with shelter and sacks for nesting. Possums were fed ad libitum fresh fruit and cereal-based possum pellets, with water freely available.

Animals were randomly allocated to control and treatment groups. For logistical reasons, the trial was split into two parts: Pep12, Pep31, and PBS control animals in trial 1 began treatment on February 26, 2002, and Pep44 and KLH control animals in trial 2 commenced treatment on March 26, 2002. For the initial immunization, about $1 \mathrm{ml}$ vaccine containing $300 \mu \mathrm{g}$ immunogen was administered subcutaneously to each female possum ( $n=20$ females per peptide) in complete Freund's adjuvant (Difco Laboratories, Detroit,
MI, USA) at four to five sites across the possum's back. Immunogen doses were repeated 3 and 6 weeks later using incomplete Freund's adjuvant (Difco Laboratories). Control animals were immunized with either PBS only $(n=10)$ or $300 \mu \mathrm{g} \mathrm{KLH}(n=10)$ administered with the same adjuvants. Possums were anesthetized by fluothane $(5 \%)$ administered in oxygen $(1.5 \mathrm{l} / \mathrm{min})$ during dosing and blood sample collection. About $3 \mathrm{ml}$ blood were collected from the ventral tail vein at weeks $0,3,6$, and at completion of the fertility assessment (week 10). Blood was transferred into serum separation tubes (SST Vacutainer Systems, Franklin Lakes, NJ, USA), allowed to clot, and centrifuged at $2000 \mathrm{~g}$ for $10 \mathrm{~min}$. Sera were removed and stored frozen at $-20{ }^{\circ} \mathrm{C}$ until analyzed.

\section{Antibody assessments}

The peptide ELISAs were carried out as described previously (Cui \& Duckworth 2005). Streptavidin plates, coated with biotinylated Pep12, Pep31, or Pep44, were used to measure antibody titers in sera and reproductive tract fluids. Reagents were supplied by Sigma Chemical Company, unless otherwise stated. Serum samples from $0,3,6$, and 10 weeks after immunization were tested at serial tenfold dilutions between $1: 10$ and $1: 10^{6}$. Absorbance values were corrected for non-specific binding and were checked for between-plate variation by including quality-control samples in each plate. A positive serum from a possum immunized against the relevant rZP2 protein was used as a quality-control sample on each plate and the color reaction was stopped when the optical density (OD) at $450 \mathrm{~nm}$ reached about 0.8-1.0 units. Endpoint titers were calculated as the highest dilution of serum where absorbance of a sample exceeded the upper $99 \%$ confidence interval of mean serum values from eight unimmunized possums at the equivalent dilutions. Titers were expressed as the mean reciprocal $\log _{10}$ dilution. Follicular fluid samples were tested at 1:1000. Oviduct, uterine, and vaginal secretions were tested undiluted and responses expressed as absorbance values corrected for non-specific binding. For the rZP2 protein ELISAs, binding of the peptide antibodies to the relevant possum rZP2 C- or N-terminal protein (Mate et al. 2003) was measured at 1:10 000 dilution of sera collected at week 10. Immuno-Plate MaxiSorb F96 flatbottomed plates (Nunc, Roskilde, Denmark, Cat. no. 4-42404) were coated overnight with $100 \mu \mathrm{l} /$ well of $5 \mu \mathrm{g} / \mathrm{ml}$ possum rZP2 C- or N-terminal protein (Mate et al. 2003) diluted in coating buffer $(50 \mathrm{mM}$ Tris- $\mathrm{HCl}$, $150 \mathrm{mM} \mathrm{NaCl}$ (pH 9.0)). Subsequent steps were identical to those of the peptide ELISA protocol (Cui \& Duckworth 2005). Serum binding to possum recombinant ZP2 protein was considered positive if the OD at $450 \mathrm{~nm}$ exceeded 0.30 units. 


\section{Superovulation protocol and laparoscopic artificial insemination}

Epididymal spermatozoa were collected from the cauda epididymides of mature male possums. Males were anesthetized with $\mathrm{CO}_{2}: \mathrm{O}_{2}$ anesthesia $\left(2 \mathrm{I} \mathrm{CO}_{2}: 1 \mid \mathrm{O}_{2}\right.$ per minute; Jolly 1993) and then killed by a single intracardiac injection of sodium pentobarbital $(125 \mathrm{mg} / \mathrm{kg}$ live weight; Chemstock Animal Health, Christchurch, Canterbury, New Zealand). Concentrated motile sperm were obtained by backflushing the vas deferens and caudal epididymis with Eagles' minimum essential media (EMEM; Sigma). Sperm motility and concentration were assessed using phase-contrast microscopy (ITM2, Olympus, Tokyo, Japan) and samples were then diluted to 50 million motile sperm per milliliter with EMEM media, stored for up to $2 \mathrm{~h}$ at 4 thinsp; ${ }^{\circ} \mathrm{C}$, and rewarmed to room temperature for insemination (Molinia et al. 1998).

Between weeks 8 and 10 after primary immunization, all female possums were treated with a single i.m. injection of 15 iu pregnant mares' serum gonadotropin (PMSG; Folligon, Intervet, Boxmeer, The Netherlands), followed $78 \mathrm{~h}$ later by a single i.m. injection of $4 \mathrm{mg}$ porcine luteinizing hormone (LH; Lutropin V, Vetrepharm, Ontario, Canada; Glazier \& Molinia 1998).

Ten to thirteen hours after the LH injection, female possums were inseminated into the vagina with the aid of a laparoscope. After a pre-med injection of $0.065 \mathrm{mg} / \mathrm{kg}$ atropine (Phoenix Pharm, Auckland, New Zealand), anesthesia was induced by i.m. injection of tiletamine chlorhydrate $(50 \mathrm{mg} / \mathrm{ml})$ and zolazepam chlorhydrate $(50 \mathrm{mg} / \mathrm{ml}$; Zoletol 100: Virbac, Techvet, Auckland, New Zealand) at a dose of $30 \mathrm{mg} / \mathrm{kg}$. Once anesthetized, animals were restrained on their back at an angle of approximately $30^{\circ}$ with their head below the abdomen to minimize risk to internal organs and to improve visualization of the contents of the pelvic cavity. Laparoscopy was performed as described by Molinia et al. (1998), except that diluted sperm $(2-3 \mathrm{ml}$ containing at least $100 \times 10^{6}$ motile spermatozoa) was injected directly into the medial vagina using a 23 gauge $\times 25 \mathrm{~mm}$ needle.

\section{Examination of reproductive tracts}

Approximately, $72-76 \mathrm{~h}$ after artificial insemination, female possums were anesthetized by $\mathrm{CO}_{2}: \mathrm{O}_{2}$ anesthesia (2 | CO $\mathrm{CO}_{2}: 1 \mathrm{I}_{2}$ per minute; Jolly 1993) and at least $5 \mathrm{ml}$ blood were collected by cardiac venipuncture for each before they were killed by overdose of sodium pentobarbital $(125 \mathrm{mg} / \mathrm{kg}$ live weight; National Veterinary Supplies, Christchurch, New Zealand). Reproductive tracts were removed and ovaries assessed for the numbers of ovulation sites and remaining unovulated follicles $(>2 \mathrm{~mm})$. Fluid from two to four unovulated ovarian follicles was collected by puncturing each follicle with a fine glass capillary tube. Oviducts, uteri, and the left lateral vagina were flushed with $1 \mathrm{ml}$ heparinized $(12.5 \mathrm{iu} / \mathrm{ml})$ PBS containing protease inhibitor (Complete, Boehringer Mannheim, Germany) to recover eggs and collect reproductive tract secretions. Eggs retrieved from oviduct and uterine flushings were stained with the DNA-specific dye Hoechst 33342 $(10 \mu \mathrm{g} / \mathrm{ml}$ in PBS, Sigma) for up to $30 \mathrm{~min}$, and then washed in PBS before examination by fluorescence microscopy (ITM2, Olympus, Tokyo, Japan). Eggs were classified as either (i) immature - germinal vesicle, metaphase I or anaphase I stage, (ii) mature unfertilized metaphase II/first polar body (PBI), (iii) embryos - early fertilized eggs with two polar bodies (PBII) and cleaving embryos, i.e. two-, four-, eight-cell, or (iv) degenerate (Molinia et al. 1998). Ovaries were fixed in Bouin's fixative and embedded in paraffin wax for follicle counting and antibody assessments.

\section{Follicular dynamics}

The right ovary from each animal was serially sectioned into $5 \mu \mathrm{m}$ sections on a microtome (R Jung, Heidelberg, Germany) and sections, in batches of six, were mounted onto poly-L-lysine-coated glass slides. Slides were ovendried at $50{ }^{\circ} \mathrm{C}$ overnight. Every fifth slide was stained for examination of follicle dynamics. This involved dewaxing the paraffin sections in Histochoice Clearing Agent (H2779, Sigma Chemical Company), followed by rehydration of the sections through graded alcohols before staining with hematoxylin (BDH 340374 T, Biolab Scientific, Christchurch, New Zealand) and eosin (Chroma 1B 419, Chroma-Gesellschaft (Schmid \& Co.), Stuttgart, Germany). Sections were then dehydrated through graded alcohols and Histochoice Clearing Agent before coverslips were mounted in DPX mountant (British Drug Houses, Poole, Dorset, UK). The slides were oven-dried at $50{ }^{\circ} \mathrm{C}$ overnight. One section from every fifth slide was photographed with an Olympus SC35 Type 12 camera (Olympus Optical Co., Tokyo, Japan) at $\times 10$ magnification using a Leica MZ12 dissection microscope (Leica Microsystems, Wetzlar, Germany). Follicles were counted at $\times 40-150$ magnification using an ITM2 microscopy (Olympus Optical Co., Japan). Follicles were classified into four classes according to categories described by Pedersen \& Peters (1968): small (Types 1-3), medium (Types 4 and 5), large (Types 6-8), and atretic. Large follicles that were present across more than five slides were only counted when the oocyte was visible. Any follicle with no visible oocyte was noted.

\section{Localization of antibodies in the ovaries by immunofluorescence}

Three sections $(5 \mu \mathrm{m})$ from the left ovary of each animal were mounted onto silanized slides (DAKO silanized 
slides, DAKO Corp., Carpinteria, CA, USA) and dried overnight at $35^{\circ} \mathrm{C}$. Sections were dewaxed and rehydrated (as described previously) and a ring was drawn around each section with a wax pen. Samples were treated with $0.1 \%(\mathrm{w} / \mathrm{v})$ trypsin (Sigma Chemical Co.) in PBS and incubated at $37^{\circ} \mathrm{C}$ for $45 \mathrm{~min}$. Slides were washed with PBS followed by two washes in PBST and then soaked for $5 \mathrm{~min}$ in PBS. Slides were blocked with $2 \%(\mathrm{w} / \mathrm{v})$ bovine serum albumin (Gibco BRL, Life Technologies) in $50 \mathrm{mM}$ glycine in a humid chamber at $37^{\circ} \mathrm{C}$ for $1 \mathrm{~h}$. Slides were then washed thrice with PBST. One section on each slide was incubated with either (i) $1: 200$ dilution of normal sheep serum $(\mathrm{v} / \mathrm{v}$; negative control) or (ii) 1:100 or 1:200 dilution of sheep antipossum IgG (supplied by Drs David Kay and Anne Kitchener, University of Newcastle, NSW, Australia) in $5 \%(\mathrm{v} / \mathrm{v})$ normal rabbit serum at $37^{\circ} \mathrm{C}$ for $90 \mathrm{~min}$. Slides were then washed and incubated with a 1:100 dilution of rabbit anti-sheep IgG (whole molecule)-FITC-conjugate antibody (Sigma Chemical Co., Cat. no. F5137) at $37^{\circ} \mathrm{C}$ for $30 \mathrm{~min}$. Slides were washed thrice with PBS and coverslips mounted using DAKO fluorescent mounting medium (DAKO Corp.). Positive controls for immunofluorescence (paraformaldehyde-fixed ovaries from possums immunized against possum rZP3 protein) were included as a test of methodology. Sections were assessed blind for background, blood vessel, ZP, and follicular fluid fluorescence on a scale of 0 (no fluorescence) to 3 (very bright fluorescence) using a fluorescence microscope (IMT2, Olympus, Tokyo, Japan). Where possible, at least ten small, four medium, and four large follicles were assessed per ovary. Fluorescence scores in blood vessels and follicular fluid, which both contained possum immunoglobulin, were used as internal controls for each slide.

\section{Binding of ZP2 peptide antibodies to native zona pellucida in vitro}

Ovaries of non-treated possums were fixed in $4 \%$ paraformaldehyde embedded in paraffin wax and sectioned for the detection of binding of possum ZP2 peptide antibodies to possum native zona using a similar method to that described earlier. After blocking, sections were incubated at $37^{\circ} \mathrm{C}$ for 90 min with serum collected at week 10 at a 1:50 dilution from each of the control and ZP2 peptide-immunized possums in the fertility trial. Additional sections were treated with 1:50 dilution of normal possum serum (negative control) or 1:100 dilution of serum from an animal immunized against the relevant possum rZP2 $\mathrm{C}$ - or $\mathrm{N}$-terminal protein (positive controls). Slides were then washed and incubated with 1:100 dilution of rabbit anti-opossum IgG heavy and light chains (Bethyl Laboratories Inc., Montgomery, TX, USA) in 5\% (v/v) normal sheep serum at $37^{\circ} \mathrm{C}$ for $45 \mathrm{~min}$. Slides were washed and incubated with a 1:100 dilution of goat anti-rabbit IgG (whole
molecule)-FITC-conjugate antibody (Sigma) at $37^{\circ} \mathrm{C}$ for $45 \mathrm{~min}$. Slides were washed thrice with PBS, coverslipped under mounting media, and sections assessed for fluorescence around the ZP.

\section{Statistical analysis}

Data from the antibody titers in sera were expressed as mean $\log _{10}$ of the reciprocal of the serum dilution. The data on follicle numbers were square root-transformed prior to analysis using one-way ANOVA. Absorbance values of antibody binding to rZP2 proteins in reproductive tract secretions and ovarian follicular fluid and numbers of ovulation sites, eggs and embryos are presented as mean values \pm s.E.M. Data analysis was carried out using one-way ANOVA. Comparisons between individual groups and the control group were analyzed using contrasts (Crawley 2002). The proportion of possums with ovulation sites, eggs, and embryos was compared between control and immunized animals using Fisher's exact test.

\section{Results}

\section{Immunogenicity of the synthetic peptide vaccines}

Possums in each of the treatment groups had antibody responses to their immunizing peptide. Antibody titers to Pep12 and Pep31 increased following each of the booster immunizations at weeks 3 and 6 with a mean titer of $10^{-5}-10^{-6}$ by week 10 (Fig. $1 \mathrm{a}$ ). The same trend was observed in possums immunized with Pep44 but there was no significant increase in immune responses after immunization at week 6 (Fig. 1b). Serum titers prior to immunization and in control animals were consistently low $(<1: 10)$. All ZP peptide-immunized possums, except one possum immunized against Pep44 (no. 2445), produced antibodies that bound to the relevant possum rZP2 protein constructs.

Binding of the ZP peptides to antibodies in the secretions from the vagina, oviduct, uterus, and ovarian follicular fluid of possums was significantly greater for Pep12, Pep31, and Pep44 (all $P<0.001$ ) than for the corresponding controls (Table 1 ).

\section{Localization of antibodies in the ovaries by immunofluorescence}

Immunofluorescence, an indicator of the presence of possum antibodies binding to the $\mathrm{ZP}$ of vaccinated animals, was present around the ZP of oocytes collected from the possums immunized against possum rZP3 protein (positive control), but was only occasionally observed at low levels around oocytes in tissue collected from the ZP2 peptide-immunized animals. Immunization with ZP2 peptides had no detectable effect on the pattern of antibody binding in the ovaries of immunized 

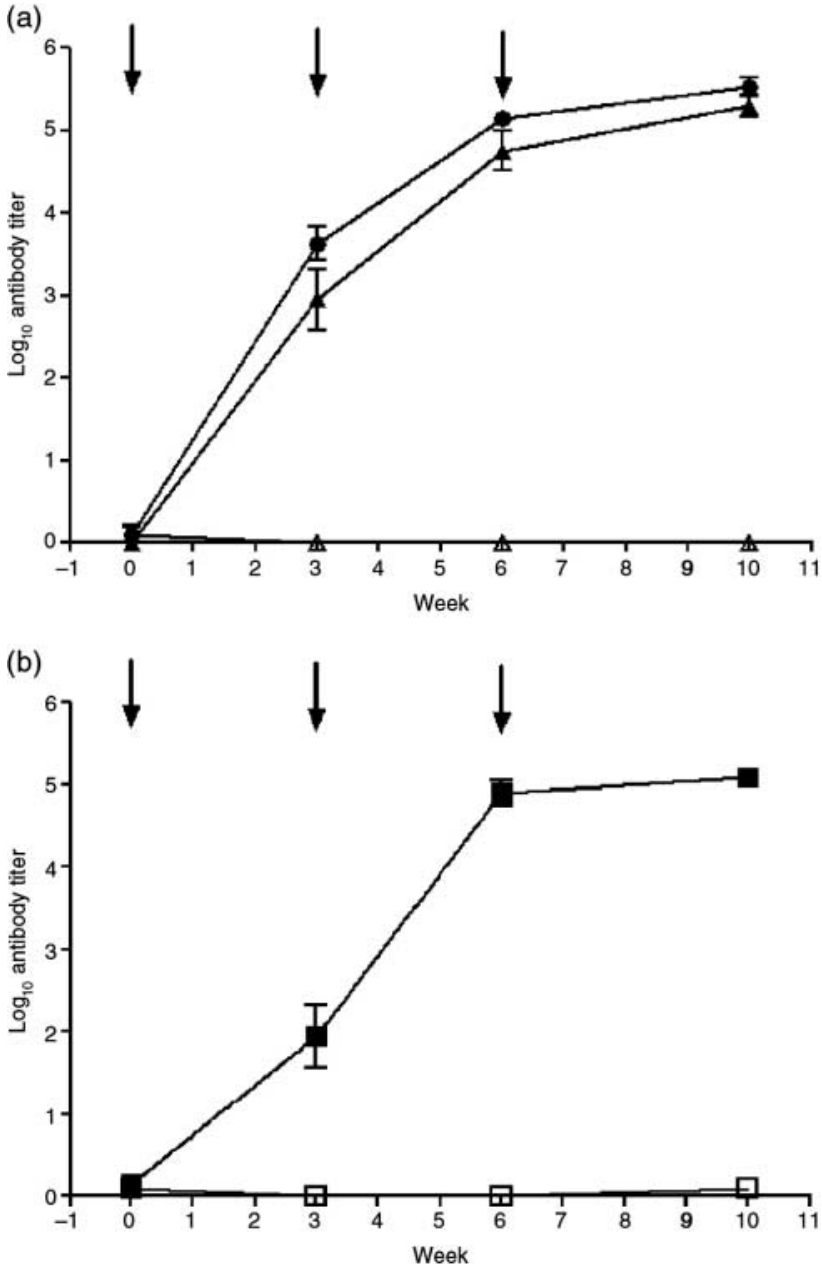

Figure 1 Antibody titers $\left(\log _{10}\right)$ in possum serum, following immunization with ZP2 Pep12 $(\boldsymbol{\Lambda} ; n=20)$ and Pep31 $(\bullet ; n=19(\mathrm{a})$, and Pep44 (ם; $n=20$; Fig. 1b). Control possums received adjuvant plus PBS only (PBS control for Pep12 and Pep31, $\rho ; n=9$ ) or adjuvant plus KLH (KLH control for Pep44, $\square ; n=10$ ). Values represent mean \pm s.E.M. Arrows indicate the times of immunization in weeks 0,3 , and 6 .

animals. There were no significant differences in differential fluorescence scores (corrected for background fluorescence) of the Pep12 $\left(F_{1,46}=0.01\right.$, $P=0.94)$, Pep31 $\left(F_{1,46}=2.16, \quad P=0.15\right)$, or Pep44
$\left(U_{10,20}=69, P=0.18\right)$ when compared with their corresponding controls.

\section{Binding of ZP2 peptide antibodies to native zona pellucida}

When serum from ZP2 peptide-immunized possums was applied to sections of paraformaldehyde-fixed ovaries from untreated possums, fluorescence was observed around the zona indicating antibody binding to the native ZP (Fig. 2). Binding was recorded with $3 / 20$ sera from Pep12-immunized animals, 3/20 sera from Pep31-immunized animals, and 20/20 sera from Pep44-immunized animals. Sera from the positive control possums, immunized with possum rZP2 protein constructs, were always positive, but not sera from control animals.

\section{Effects of immunization on ovulatory responses and possum fertility}

The number of ovulation sites counted on the possum ovaries varied greatly between animals but was not affected significantly by the immunization treatments with Pep12, Pep31, or Pep44 (all $P>0.05$ ). Immunization with ZP2 peptides had no significant effect on the total number of eggs of possums immunized with Pep12, Pep31, or Pep44 (all $P>0.05$; Tables 2 and 3). The number of embryos of immunized animals was not affected significantly by immunizations with peptides Pep12 $\left(F_{1,46}=1.15, P=0.29\right)$ and Pep31 $\left(F_{1,46}=0.72\right.$, $P=0.40$; Table 2), but animals immunized against Pep44 had significantly fewer embryos (79\% reduction) than control animals (immunized 0.5 embryos versus control 2.4 embryos; $U_{10,20}=53, P=0.039$; Tables 3 ). Immunization against Pep44 resulted in a lower percentage of eggs being fertilized $\left(U_{10,20}=43, P=0.011\right.$; Table 3$)$, but there were no effects on the fertilization rates of eggs from Pep12 $\left(F_{1,46}=0.47, \quad P=0.50\right) \quad$ or Pep31 $\left(F_{1,46}=1.85, P=0.16\right)$ immunized possums (Table 2$)$.

There were no significant differences using Fisher's exact test in the percentage of females with eggs present between control and treatment groups following

Table 1 Binding of antibodies in possum reproductive tract following immunization with ZP2 peptide, PBS, or keyhole limpet hemocyanin vaccines.

\begin{tabular}{|c|c|c|c|c|c|}
\hline & & Vagina & Oviduct & Uterus & Follicular fluid \\
\hline \multirow[t]{6}{*}{ Trial 1} & PBS control $(n=9)$ & $0.16 \pm 0.05$ & $0.24 \pm 0.06$ & $0.28 \pm 0.08$ & $0.04 \pm 0.01$ \\
\hline & Pep12 $(n=20)$ & $0.51 \pm 0.04 *$ & $1.04 \pm 0.01 *$ & $0.92 \pm 0.04^{*}$ & $1.04 \pm 0.02 *$ \\
\hline & & $F_{1,46}=23.8$ & $F_{1,46}=345.0$ & $F_{1,46}=73.5$ & $F_{1,46}=1010.8$ \\
\hline & & $P<0.001$ & $P<0.001$ & $P<0.001$ & $P<0.001$ \\
\hline & Pep31 $(n=19)$ & $0.50 \pm 0.05^{*}$ & $0.97 \pm 0.03 *$ & $0.92 \pm 0.04 *$ & $0.88 \pm 0.02 *$ \\
\hline & & $\begin{array}{c}F_{1,46}=21.6 \\
P<0.001\end{array}$ & $\begin{array}{c}F_{1,46}=288.6 \\
P<0.001\end{array}$ & $\begin{array}{c}F_{1,46}=72.4 \\
P<0.001\end{array}$ & $\begin{array}{c}F_{1,46}=687.5 \\
P<0.001\end{array}$ \\
\hline \multirow[t]{4}{*}{ Trial 2} & KLH control $(n=10)$ & $0.11 \pm 0.02$ & $0.12 \pm 0.02$ & $0.12 \pm 0.02$ & $0.033 \pm 0.00$ \\
\hline & Pep44 $(n=20)$ & $0.42 \pm 0.04 *$ & $0.84 \pm 0.06 *$ & $0.72 \pm 0.04 *$ & $0.78 \pm 0.02 *$ \\
\hline & & $U_{10,20}=13$ & $U_{10,20}=0.0$ & $U_{10,20}=0.0$ & $U_{9,15}=0.0$ \\
\hline & & $P<0.001$ & $P<0.001$ & $P<0.001$ & $P<0.001$ \\
\hline
\end{tabular}

All values are mean \pm S.E.M. *Value is significantly different from corresponding control value $(P<0.001)$. 

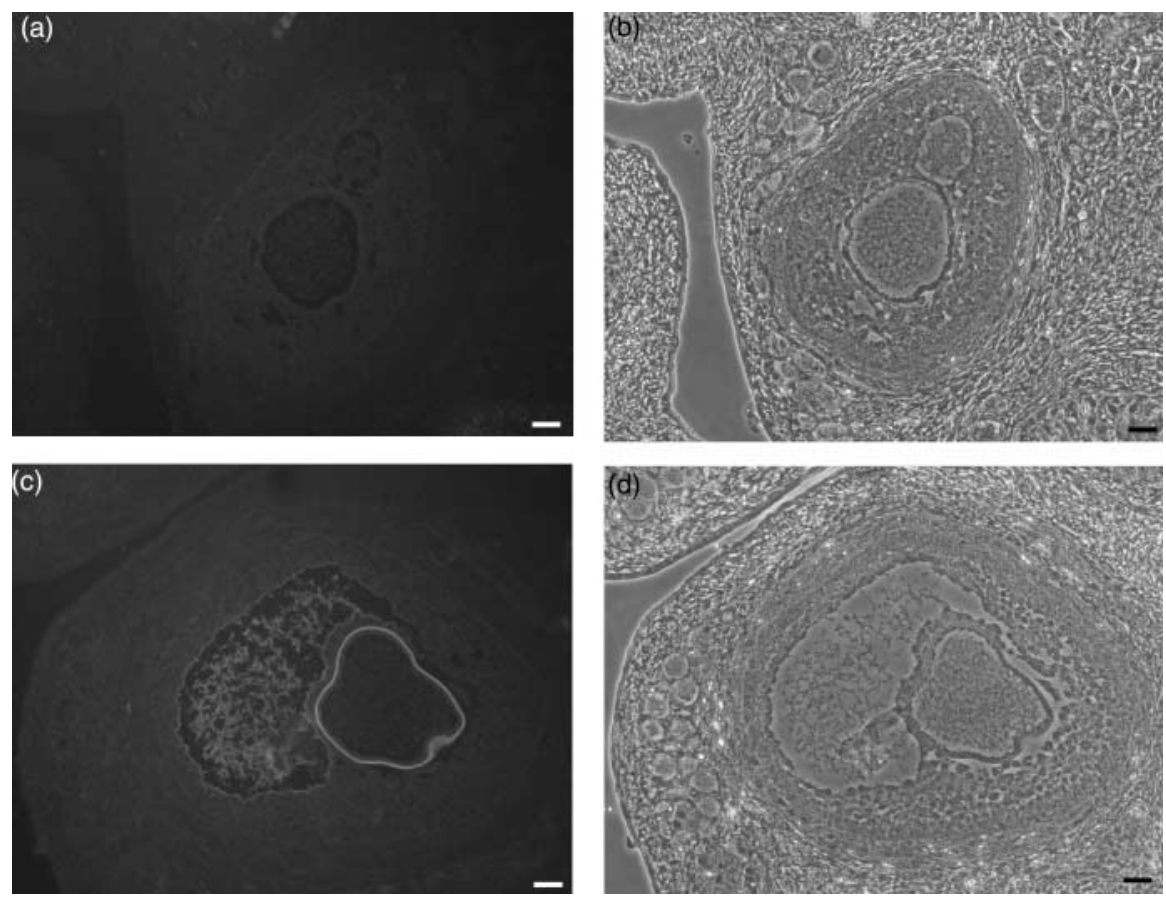

Figure 2 Paired fluorescence and phasecontrast micrographs $(\times 300)$ showing binding to zona in paraformaldehyde-fixed ovarian sections treated with sera from a control ( $\mathrm{a}$ and b) or Pep44-immunized possum (c and d). immunization with the Pep12 $(P=0.63)$, Pep31 $(P=1.0)$, or Pep44 peptides $(P=0.20$; Table 2$)$. There were no significant differences in the percentage of females with embryos present between control and treatment groups following immunization with the Pep12 $(P=1.0)$ or Pep31 peptides $(P=1.0)$, but there was a significant decrease following immunization with peptide Pep44 $(P=0.045$; Table 3$)$. The number of Pep44-immunized females that produced embryos following immunization was reduced by $64 \%$ compared with controls.

\section{Follicular dynamics}

When compared with their corresponding control possums, there were no significant differences for any of the three peptides in the numbers of small, medium, large, or atretic follicles (Table 4, all $P>0.05$ ). There was no evidence of invasion of ovarian follicles by lymphocytes and granulocytes and no ovarian pathology was observed in ZP2 peptide-immunized animals.

\section{Discussion}

Immunization with native ZP or recombinant ZP proteins impairs fertility in a range of species, and the underlying mechanisms causing immunocontraception are complex (Barber \& Fayrer-Hoskin 2000). Antibodies against ZP proteins are thought to block fertilization at the site of sperm-zona interaction (Henderson et al. 1988, Sacco et al. 1989) and prevent sperm penetration of the ZP (East et al. 1985, Mahi-Brown et al. 1985, Bamezai et al. 1988). Binding of ZP antibodies to the oocytes may also trigger premature exocytosis of the cortical granules such that spermatozoa are incapable of fertilizing the egg (Ducibella 1996). A recent proposal for the process of sperm-egg recognition emphasizes the importance of the

Table 2 Effect of immunization with ZP2 peptides Pep12 and Pep31 on the numbers of ovulation sites, eggs, and embryos recovered from possums, and fertilization rates for those possums with eggs present.

\begin{tabular}{|c|c|c|c|c|c|c|}
\hline Treatment & $\begin{array}{c}\text { Number of } \\
\text { ovulation sites }\end{array}$ & $\begin{array}{l}\text { Number } \\
\text { of eggs }\end{array}$ & $\begin{array}{c}\text { Number of } \\
\text { embryos }\end{array}$ & $\begin{array}{l}\text { Fertilization rate } \\
\text { (\% eggs fertilized) }\end{array}$ & $\begin{array}{c}\text { Number of females } \\
\text { with eggs present }(\%)\end{array}$ & $\begin{array}{l}\text { Number of females with } \\
\text { embryos present }(\%)\end{array}$ \\
\hline PBS control $(n=9)$ & $7.6 \pm 3.2$ & $2.4 \pm 1.0$ & $0.9 \pm 0.4$ & $53.7 \pm 22.9$ & $7 / 9(78 \%)$ & $5 / 9(56 \%)$ \\
\hline \multirow[t]{2}{*}{ Pep12 $(n=20)$} & $5.8 \pm 1.0$ & $3.3 \pm 0.7$ & $1.7 \pm 0.5$ & $60.7 \pm 11.2$ & $17 / 20(85 \%)$ & $11 / 20(55 \%)$ \\
\hline & $\begin{array}{c}F_{1,46}=1.46 \\
P=0.23\end{array}$ & $\begin{array}{c}F_{1,46}=0.05 \\
P=0.83\end{array}$ & $\begin{array}{c}F_{1,46}=1.15 \\
P=0.29\end{array}$ & $\begin{array}{l}F_{1,46}=0.47 \\
P=0.50\end{array}$ & $\begin{array}{c}\text { Fisher's exact test } \\
\qquad P=0.63\end{array}$ & $\begin{array}{c}\text { Fisher's exact test } \\
\qquad P=1.0\end{array}$ \\
\hline \multirow[t]{2}{*}{ Pep31 $(n=19)$} & $5.4 \pm 1.4$ & $4.1 \pm 1.7$ & $1.4 \pm 0.5$ & $62.2 \pm 12.5$ & $13 / 19(68 \%)$ & $10 / 19(53 \%)$ \\
\hline & $\begin{array}{c}F_{1,46}=1.62 \\
P=0.21\end{array}$ & $\begin{array}{c}F_{1,46}=0.05 \\
P=0.83\end{array}$ & $\begin{array}{c}F_{1,46}=0.72 \\
P=0.40\end{array}$ & $\begin{array}{c}F_{1,46}=1.85 \\
P=0.16\end{array}$ & $\begin{array}{c}\text { Fisher's exact test } \\
\qquad P=1.0\end{array}$ & $\begin{array}{c}\text { Fisher's exact test } \\
\qquad P=1.0\end{array}$ \\
\hline
\end{tabular}

All values are mean \pm S.E.M. 
Table 3 Effect of immunization with ZP2 peptide Pep44 on the numbers of ovulation sites, eggs, and embryos recovered from possums, and fertilization rates for those possums with eggs present.

\begin{tabular}{|c|c|c|c|c|c|c|}
\hline Treatment & $\begin{array}{c}\text { Number of } \\
\text { ovulation sites }\end{array}$ & $\begin{array}{c}\text { Number of } \\
\text { eggs }\end{array}$ & $\begin{array}{l}\text { Number of } \\
\text { embryos }\end{array}$ & $\begin{array}{l}\text { Fertilization rate } \\
(\% \text { eggs fertilized })\end{array}$ & $\begin{array}{l}\text { Number of females } \\
\text { with eggs present }\end{array}$ & $\begin{array}{l}\text { Number of females with } \\
\text { embryos present }\end{array}$ \\
\hline KLH control $(n=10)$ & 5. & 3.4 & 2. & 60 & $9 / 1$ & $7 /$ \\
\hline \multirow[t]{2}{*}{ Pep44 $(n=20)$} & $4.6 \pm 0.9$ & $2.0 \pm 0.5$ & $0.5 \pm 0.2^{*}$ & $19.5 \pm 9.1 *$ & $12 / 20(60 \%)$ & $5 / 20 *(25 \%)$ \\
\hline & $\begin{array}{c}U_{10,20}=94 \\
P=0.81\end{array}$ & $\begin{array}{c}U_{10,20}=82 \\
P=0.45\end{array}$ & $\begin{array}{c}U_{10,20}=53 \\
P=0.039\end{array}$ & $\begin{array}{c}U_{10,20}=43 \\
P=0.011\end{array}$ & $\begin{array}{c}\text { Fisher's exact test } \\
P=0.20\end{array}$ & $\begin{array}{c}\text { Fisher's exact test } \\
P=0.045\end{array}$ \\
\hline
\end{tabular}

All values are mean \pm s.E.M. $*$ Value is significantly different from control value $(P<0.05)$.

three-dimensional structure of the ZP in determining sperm binding, rather than the role of a single protein or carbohydrate (Hoodbhoy \& Dean, 2004). This implies that antibody binding may also result in infertility by changing the conformation of the three-dimensional structure of the zona matrix, rather than simply blocking access to epitopes on individual ZP proteins. There is also evidence that antibodies against ZP antigens alter the distribution of $T$ cell-mediated inflammation and result in destruction of the functional components within the ovary (Lou et al. 2000), possibly destroying oocytes via a cell-mediated cytotoxic immune response (Jackson et al. 1998).

In this study, antibody binding was detected in possum sera and fluids from the vagina, oviduct, uterus, and ovarian follicle of immunized animals. This indicates that all three ZP2 peptides had the ability to stimulate the production of antibodies against relevant peptides and that the antibodies reached the target sites of the follicular fluid around the oocyte, at the site of fertilization in the oviduct, and the site of embryonic development in the uterus. Jethanandani et al. (1998) showed that antibodies raised in rabbits against a bonnet monkey ZP2 peptide recognized bonnet monkey ZP in its native form within the ovary, as indicated by intense fluorescence of antibodies bound to the ZP. Similarly, immunization of possums against porcine ZP or a possum ZP3 peptide (Duckworth et al. 1999) and wallabies against porcine ZP (Kitchener et al. 2002) stimulated the accumulation of Ig antibodies around the ZP in antral follicles of immunized animals but not in the controls. In this study, no significant antibody binding to native ZP was detected in the ovarian follicles of the peptide-immunized animals but this is likely to have been an artifact arising from the use of Bouin's reagent as the tissue fixative. Fixation with Bouin's reagent has been shown to almost completely destroy the ZP structure of mammalian oocytes whereas formalin-based fixatives did not (Eberspaecher et al. 2001). It is therefore not possible to comment on the in vivo binding of antibodies to ZP of treated possums. However, antibodies in serum from possum immunized against the ZP2 peptides, particularly peptide 44 , did bind to the possum zona in vitro demonstrating that the Pep44 antibodies recognize possum $\mathrm{ZP}$ in its native form.

Immunization against Pep44 reduced the egg fertilization rate and embryo production of immunized animals but had no significant effect on egg production or follicular development, suggesting that reproductive impairment resulted from disruption of the fertilization process rather than oocyte production. This is consistent with the findings that Pep44 binds to the acrosome and midpiece of possum spermatozoa (Cui \& Duckworth 2005), and that antibodies against Pep44 bind to native zona. Pep44 is thus a suitable candidate for immunocontraceptive fertility control in possums. Failure of peptides Pep12 or Pep31 to reduce fertility and for their antibodies to reliably bind to native zona suggests that they may not be genuine immunocontraceptive epitopes.

Jackson et al. (1998) postulated that in mice, antibodies binding to the developing ZP of growing eggs may disrupt folliculogenesis, possibly by killing

Table 4 Numbers of small, medium, large, and atretic follicles per ovary in possums following immunization with ZP2 peptides, PBS, or keyhole limpet hemocyanin.

\begin{tabular}{|c|c|c|c|c|c|}
\hline & & Small & Medium & Large & Atretic \\
\hline \multirow{6}{*}{ Trial 1} & PBS control $(n=9)$ & $3311.9 \pm 743.6$ & $93.6 \pm 19.7$ & $37.4 \pm 8.4$ & $4.4 \pm 0.9$ \\
\hline & Pep12 $(n=20)$ & $1969.8 \pm 686.0$ & $88.9 \pm 28.8$ & $27.0 \pm 6.6$ & $5.6 \pm 1.2$ \\
\hline & & $F_{1,21}=2.54$ & $F_{1,46}=0.22$ & $F_{1,46}=1.06$ & $F_{1,46}=0.58$ \\
\hline & & $P=0.13$ & $P=0.64$ & $P=0.32$ & $P=0.45$ \\
\hline & Pep31 $(n=19)$ & $2280.3 \pm 437.8$ & $56.6 \pm 10.3$ & $29.6 \pm 6.2$ & $5.5 \pm 1.4$ \\
\hline & & $\begin{array}{c}F_{1,46}=0.95 \\
P=0.34\end{array}$ & $\begin{array}{c}F_{1,46}=1.38 \\
P=0.25\end{array}$ & $\begin{array}{c}F_{1,46}=0.59 \\
P=0.45\end{array}$ & $\begin{array}{c}F_{1,46}=0.47 \\
P=0.50\end{array}$ \\
\hline \multirow[t]{4}{*}{ Trial 2} & KLH control $(n=10)$ & $3219.1 \pm 834.3$ & $60.8 \pm 9.6$ & $42.0 \pm 9.3$ & $5.6 \pm 2.0$ \\
\hline & Pep44 $(n=20)$ & $3232.3 \pm 663.5$ & $61.4 \pm 1.0$ & $31.8 \pm 6.3$ & $5.8 \pm 1.5$ \\
\hline & & $U_{8,8}=31$ & $U_{8,8}=30.5$ & $U_{8,8}=26$ & $U_{8,8}=29.5$ \\
\hline & & $P=0.96$ & $P=0.88$ & $P=0.57$ & $P=0.80$ \\
\hline
\end{tabular}

All values are mean \pm S.E.M. 
oocytes via antibody-dependent cell-mediated cytotoxicity or complement lysis. Cellular and cytokine responses to immunization with $\mathrm{ZP}$ antigens have been shown to be critical in determining the fertility status of individual mice through the processes that lead to oophoritis (Lou et al. 2000). In mice, the incidence of oophoritis and inflammatory ( $\mathrm{T}$ cell) responses in the ovary following ZP3 immunization varies depending on mouse major histocompatibility complex (MHC) haplotype and the presence of a pathology-inducing $\mathrm{T}$ cell epitope within the antigen construct (Lou et al. 1996, Bagavant et al. 1999). A strong $T$ cell response that depleted oocyte populations in immunized animals would be advantageous for a long-acting contraceptive vaccine to control wildlife pest species such as the possum. Immunization of possums against recombinant possum ZP2 proteins significantly reduced the number of eggs produced following superovulation and artificial insemination, but without detectable ovarian pathology (Duckworth unpublished data). Even though the possum ZP2 peptides used in this study were defined using sera of infertile animals immunized with possum rZP2, both humoral and cellular immunity may play a role in inducing infertility in the Pep44-immunized possums. This is the subject of current investigations. However, in the present study, immunization was not associated with a reduction in egg production, the depletion of developing ovarian follicles, or an increase in the number of atretic follicles in the treated animals. There was also no evidence of invasion of ovarian follicles by lymphocytes and granulocytes as described by Sun et al. (1999) following immunization of mice with murine ZP3 ${ }^{330-342}$ peptide

Finally, immunization with ZP antigens may have additional effects on reproductive success beyond disruption of oocyte development and fertilization. In the present study, fertility was assessed about day 3 of gestation following superovulation and artificial insemination. In possums, the choriovitelline placenta does not form until day 13 of the 17-day gestation period (Hughes \& Hall 1984, Fletcher \& Selwood 2000), so any effects of immunization on placental-uterine contact would need to be assessed in a natural breeding trial where embryos were permitted to develop to full term.

New Zealand has no native marsupials. The identification of regions in ZP proteins that are unique to possum/marsupial species and play a key role in reproduction may offer an important advantage for the development of a species-specific method of fertility control. Within eutharian species ZP proteins are highly conserved, with amino acid identities between 54 and $77 \%$ (Epifano \& Dean 1994), and immunization of a species with heterologous ZP proteins often results in a reduction in fertility (Hasegawa et al. 1992, Bagavant et al. 1994, 1999, Kirkpatrick et al. 1996, 1997, Miller et al. 1999). ZP2 sequences of possum and eutharian species share only $48-54 \%$ identity at the amino acid level, with most identity restricted to the ZP domain (Mate \& McCartney 1998). One reason for developing ZP peptide vaccines is the potential to make the vaccines species specific. Targeting epitopes critical to reproduction may confer species specificity if such epitopes are not shared with non-target species (Hinsch et al. 1999). One unique epitope located in the variable region of possum ZP3 (McCartney \& Mate 1999), which corresponds to the region of a mouse infertility epitope (Millar et al. 1989), has been identified as an immunocontraceptive possum epitope (Duckworth et al. 1999). The ZP2 antigen Pep44 is more highly conserved (Cui \& Duckworth 2005), but the corresponding region has not been identified to date as a contraceptive epitope in any other species. ZP antigens including Pep44 and the possum ZP3 epitope are being assessed for their effect on the fertility of model eutharian and avian species. In addition, detailed mapping of Pep44 by the alaninescanning technique has identified several critical amino acids. Modified peptide sequences that are potentially more possum specific are being constructed for further testing. Since administration of immunocontraceptive vaccines by injection is impractical for field-based delivery, a range of delivery systems are currently under development, including edible plant-derived vaccines and bacterial ghost vaccines for oral and/or aerosol delivery (Duckworth et al. 1999). Some of the vaccine systems being developed cannot express large recombinant proteins, so smaller immunocontraceptive peptides are required. Identification of a range of species-specific ZP antigens will assist the development of safe, humane, and possum-specific immunocontraceptive vaccines for the control of the fertility of introduced possums in New Zealand.

\section{Acknowledgements}

The authors thank Karen Mate and Janine Buist from the Cooperative Research Centre for Conservation and Management of Marsupials, University of Newcastle, Australia, for supplying possum ZP2 sequences and recombinant possum ZP2 protein for vaccines; Susie Scobie, Catherine Condon, Jane Arrow, Ian Ellis, Vaughan Myers, and the Animal Facility staff provided technical assistance. This research was supported by the New Zealand Foundation for Research, Science and Technology (contract no. C09X0209) and the Australian Government Marsupial Cooperative Research Centre. The authors declare that there is no conflict of interest that would prejudice the impartiality of this scientific work.

\section{References}

Bagavant H, Thillai-Koothan P, Sharma MG, Talwar GP \& Gupta SK 1994 Antifertility effects of porcine zona pellucida-3 immunization using permissible adjuvants in female bonnet monkeys (Macaca radiata): reversibility, effect on follicular development and hormonal profiles. Journal of Reproduction and Fertility 102 17-25. 
Bagavant H, Adams S, Terranova P, Chang A, Kraemer FW, Lou Y, Kasai K, Luo AM \& Tung KS 1999 Autoimmune ovarian inflammation triggered by proinflammatory (Th1) T cells is compatible with normal ovarian function in mice. Biology of Reproduction 61 635-642.

Bamezai AK, Mahi-Brown CA \& Talwar GP 1988 Inhibition of penetration of canine zonae pellucidae by homologous spermatoza in vitro using monoclonal antibodies raised against porcine zonae. Journal of Reproductive Immunology 13 85-95.

Barber MR \& Fayrer-Hosken RA 2000 Possible mechanisms of mammalian immunocontraception. Journal of Reproductive Immunology 46 103-124.

Bhatnagar P, Gupta SK \& Sehgal S 1992 Immunogenicity of deglycosylated zona pellucida antigens and their inhibitory effects on fertility in rabbits. International Journal of Fertility 37 53-63.

Buddle BM, Aldwell FE, Jowett G, Thomson R, Jackson R \& Paterson BM 1992 Influence of stress of capture on haematological values and cellular immune responses in the Australian brushtail possum (Trichosurus vulpecula). New Zealand Veterinary Journal 40 155-159.

Clydesdale G, Pekin J, Beaton S, Jackson RJ, Vignarajan S \& Hardy CM 2004 Contraception in mice immunized with recombinant zona pellucida subunit 3 proteins correlates with Th2 responses and the levels of interleukin 4 expressed by CD4 + cells. Reproduction 128 737-745.

Cowan PE 2000 Biological control of possums: prospects for the future. In The Brushtail Possum: Biology, Impact and Management of an Introduced Marsupial, pp 262-270. Ed. TL Montague. Lincoln, New Zealand: Manaaki Whenua Press.

Crawley MJ 2002 Statistical Computing: An Introduction to Data Analysis using S-Plus, Chichester, UK: Wiley.

Cui X \& Duckworth JA 2005 Mapping of B cell epitopes on the zona pellucida 2 protein of a marsupial, the brushtail possum (Trichosurus vulpecula). Molecular Reproduction and Development 70 485-493.

Dietl J, Freye J \& Mettler L 1982 Fertility inhibition using low-dose immunization with procine zonae pellucidae. American Journal of Reproductive Immunology 2 153-156.

Ducibella T 1996 The cortical reaction and development of activation competence in mammalian oocytes. Human Reproduction Update $\mathbf{2}$ 29-42.

Duckworth JA, Harris M, Mate K, McCartney C, Buist J, Scobie S, Jones D \& Jones S 1999 Development of brushtail possum immunocontraception: targeting sperm and egg antigens. In Advances in the Biological Control of Possums, pp 72-76. Ed. G Sutherland. Royal Society New Zealand Miscellaneous Series 56, Wellington, New Zealand.

Duckworth JA, Byrom AE, Fisher P \& Horn C 2006 Pest control: does the answer lie in new biotechnologies? In Biological Invasions in New Zealand. Ecological Studies, Vol. 186, pp 421-434. Eds RB Allen \& WG Lee. Berlin: Springer-Verlag.

East IJ, Gulyas BJ \& Dean J 1985 Monoclonal antibodies to the murine zona pellucida protein with sperm receptor activity: effects on fertilization and early development. Developmental Biology 109 268-273.

Eberspaecher U, Becker A, Bringmann P, van der Merwe $\mathbf{L}$ \& Donner $\mathbf{P}$ 2001 Immunohistochemical localization of zona pellucida proteins ZPA, ZPB and ZPC in human, cynomolgus monkey and mouse ovaries. Cell Tissue Research 303 277-287.

Epifano O \& Dean J 1994 Biology and structure of the zona pellucida: a target for immunocontraception. Reproduction, Fertility and Development 6 319-330.

Fletcher T \& Selwood L 2000 Possum reproduction and development. In The Brushtail Possum: Biology, Impact and Management of an Introduced Marsupial, pp 62-81. Ed. TL Montague. Lincoln, New Zealand: Manaaki Whenua Press.

Frank KM, Lyda RO \& Kirkpatrick JF 2005 Immunocontraception of captive exotic species: IV. Species differences in response to the porcine zona pellucida vaccine, timing of booster inoculations, and procedural failures. Zoo Biology 24 349-358.
Glazier AM \& Molinia FC 1998 Improved method of superovulation in monovulatory brushtail possums (Trichosurus vulpecula) using pregnant mares' serum gonadotrophin-luteinizing hormone. Journal of Reproduction and Fertility 113 191-195.

Govind CK, Srivastava N \& Gupta SK 2002 Evaluation of the immunocontraceptive potential of Escherichia coli expressed recombinant non-human primate zona pellucida glycoproteins in homologous animal model. Vaccine 21 78-88.

Gupta SK, Srivastava N, Choudhury S, Rath A, Sivapurapu N, Gahlay GK \& Batra D 2004 Update on zona pellucida glycoproteins based contraceptive vaccine. Journal of Reproductive Immunology $6279-89$.

Harris JD, Hibler DW, Fontenot GK, Hsu KT, Yurewicz EC \& Sacco AG 1994 Cloning and characterization of zona pellucida genes and cDNAs from a variety of mammalian species: the ZPA, ZPB and ZPC gene families. DNA Sequence 4 361-393.

Hasegawa A, Koyama K, Inoue M, Takemura T \& Isojima S 1992 Antifertility effect of active immunization with ZP4 glycoprotein family of porcine zona pellucida in hamsters. Journal of Reproductive Immunology 22 197-210.

Henderson CJ, Hulme MJ \& Aitken RJ 1988 Contraceptive potential of antibodies to the zona pellucida. Journal of Reproduction and Fertility 83 325-343.

Hinsch E, Oehninger S, Schill WB \& Hinsch KD 1999 Species specificity of human and murine anti-ZP3 synthetic peptide antisera and use of the antibodies for localization and identification of ZP3 or ZPC domains of functional significance. Human Reproduction $\mathbf{1 4}$ 419-428.

Hoodbhoy T \& Dean J 2004 Insights into the molecular basis of spermegg recognition in mammals. Reproduction 127 417-422.

Hughes RL \& Hall LS 1984 Embryonic development in the common brushtail possum Trichosurus vulpecula. In Possums and Gliders, pp 197-212. Eds AP Smith \& ID Hume. Sydney: Surrey Beatty \& Sons with Australian Mammal Society.

Jackson RJ, Maguire DJ, Hinds LA \& Ramshaw IA 1998 Infertility in mice induced by a recombinant ectromelia virus expressing mouse zona pellucida glycoprotein 3. Biology of Reproduction 58 152-159.

Jethanandani P, Santhanam R \& Gupta SK 1998 Molecular cloning and expression in Escherichia coli of cDNA encoding bonnet monkey (Macaca radiata) zona pellucida glycoprotein-ZP2. Molecular Reproduction and Development 50 229-239.

Jolly SE 1993 Carbon dioxide as an anaesthetic agent for use on the brushtail possum (Marsupialia: phalangeridae). Australian Mammalogy 16 67-68.

Kerr PJ, Jackson RJ, Robinson AJ, Swan J, Silvers L, French N, Clarke H, Hall DF \& Holland MK 1999 Infertility in female rabbits (Oryctolagus cuniculus) alloimmunized with the rabbit zona pellucida protein ZPB either as a purified recombinant protein or expressed by recombinant myxoma virus. Biology of Reproduction 61 606-613.

Kirkpatrick JF, Turner JW Jr, Liu IK \& Fayrer-Hosken R 1996 Applications of pig zona pellucida immunocontraception to wildlife fertility control. Journal of Reproduction and Fertility Supplementary 50 183-189.

Kirkpatrick JF, Turner JW Jr, Liu IK, Fayrer-Hosken R \& Rutberg AT 1997 Case studies in wildlife immunocontraception: wild and feral equids and white-tailed deer. Reproduction, Fertility and Development 9 105-110.

Kirkpatrick JF \& Frank KM 2005 Contraception in free-ranging wildlife. In Wildlife Contraception: Issues, Methods, and Applications, pp 195-221. Eds CS Ada \& IJ Porton. Baltimore: John Hopkins University Press.

Kitchener AL, Edds LM, Molinia FC \& Kay DJ 2002 Porcine zonae pellucidae immunization of tammar wallabies (Macropus eugenii): fertility and immune responses. Reproduction, Fertility, and Development 14 215-223.

Lee AC, Powell JE, Tregear GW, Niall HD \& Stevens VC 1980 A method for preparing beta-hCG $\mathrm{COOH}$ peptide-carrier conjugates of predictable composition. Molecular Immunology 17 749-756. 
Lou YH, Bagavant H, Ang J, McElveen E, Thai H \& Tung KSK 1996 Influence of autoimmune ovarian disease pathogenesis on ZP3 contraceptive vaccine design. Journal of Reproduction and Fertility 50 159-163.

Lou YH, Park KK, Agersborg S, Alard P \& Tung KS 2000 Retargeting T cell-mediated inflammation: a new perspective on autoantibody action. Journal of Immunology 164 5251-5257.

Mackenzie SM, McLaughlin EA, Perkins HD, French N, Sutherland T, Jackson RJ, Inglis B, Müller WJ, van Leeuwen BH, Robinson AJ \& Kerr PJ 2006 Immunocontraceptive effects on female rabbits infected with recombinant myxoma virus expressing rabbit ZP2 or ZP3. Biology of Reproduction 74 511-521.

Mahi-Brown CA, Yanagimachi R, Hoffman JC \& Huang TT Jr 1985 Fertility control in the bitch by active immunization with porcine zonae pellucidae: use of different adjuvants and patterns of oestadiol and progesterone levels in oestous cycles. Biology of Reproduction $32761-772$.

Mate KE \& McCartney CA 1998 Sequence and analysis of zona pellucida 2 cDNA (ZP2) from a marsupial, the brushtail possum, Trichosurus vulpecula. Molecular Reproduction and Development 51 322-329.

Mate KE, Buist JM \& Duckworth JA 2003 Expression in Escherichia coli and immunological characterization of three zona pellucida proteins (ZP1, ZP2, and ZP3) from a marsupial, the brushtail possum (Trichosurus vulpecula). Molecular Reproduction and Development 64 136-143.

McCartney CA \& Mate KE 1999 Cloning and characterization of a zona pellucida 3 cDNA from a marsupial, the brushtail possum Trichosurus vulpecula. Zygote 7 1-9.

Millar SE, Chamow SM, Baur AW, Oliver C, Robey F \& Dean J 1989 Vaccination with a synthetic zona pellucida peptide produces longterm contraception in female mice. Science 246 935-938.

Miller LA, Johns BE \& Killian GJ 1999 Long-term effects of PZP immunization on reproduction in white-tailed deer. Vaccine $\mathbf{1 8}$ 568-574.
Molinia FC, Gibson RJ, Brown AM, Glazier AM \& Rodger JC 1998 Successful fertilization after superovulation and laparoscopic intrauterine insemination of the brushtail possum, Trichosurus vulpecula, and tammar wallaby Macropus eugenii. Journal of Reproduction and Fertility 113 9-17.

Pedersen T \& Peters H 1968 Proposal for the classification of oocytes and follicles in the mouse ovary. Journal of Reproduction and Fertility 17 555-557.

Sacco AG, Yurewicz EC \& Subramanian MG 1989 Effect of varying dosages and adjuvants on antibody response in squirrel monkeys (Saimiri sciureus) immunized with the porcine zona pellucida $\mathrm{Mr}=55,000$ glycoprotein (ZP3). American Journal of Reproductive Immunology 21 1-8.

Srivastava N, Santhanam R, Sheela P, Mukund S, Thakral SS, Malik BS \& Gupta SK 2002 Evaluation of the immunocontraceptive potential of Escherichia coli-expressed recombinant dog ZP2 and ZP3 in a homologous animal model. Reproduction 123 847-857.

Sun W, Lou YH, Dean J \& Tung KSA 1999 A contraceptive peptide vaccine targeting sulfated glycoprotein ZP2 of the mouse zona pellucida. Biology of Reproduction 60 900-907.

Tribbick G 1993 Developments in ELISA: the use of biotinylated peptides in the assessment of antipeptide sera. American Biotechnology Laboratory 1132.

Turner JW Jr, Liu IK \& Kirkpatrick JF 1996 Remotely delivered immunocontraception in free-roaming feral burros (Equus asinus). Journal of Reproduction and Fertility 107 31-35.

Wassarman PM 2005 Contribution of mouse egg zona pellucida glycoproteins to gamete recognition during fertilization. Journal of Cellular Physiology 204 388-391.

Received 29 June 2006

First decision 27 July 2006

Revised manuscript received 3 September 2006

Accepted 30 October 2006 